\title{
Guillermo Del TORO's POlitical FAIRY TAles
}

\author{
Elizabeth Abele \\ Gulf University for Science E Technology
}

\section{ABSTRACT}

While critical attention has largely focused on Del Toro's overt fairy tale Pan's Labyrinth (2006), Del Toro's Hollywood films similarly incorporate the mythic, moral, and gothic qualities of classic fairy tales. His new fairy tales present vital contemporary lessons embedded in these archetypal journeysand their audience's memories. His free borrowings from fairy tales and popular culture deliberately connect the familiar to his uncanny worlds. This construction is most evident in his films Hellboy II: The Golden Army (2008) and The Shape of Water (2017). The contemporary politics of race, sexuality, gender, and environmentalism are embedded within these original Hollywood fairy tales. This essay focuses on the intersecting political messages woven into Hellboy II: The Golden Army and The Shape of Water, messages amplified not obscured by their fairy tale delivery. Through rich textual references, intersections, and hidden subtexts, Del Toro creates new gothic fairy tales, with original protagonists, emerging from the margins. By resisting previous patriarchal and racial boundaries, these films challenge their audiences to embrace new paradigms.

Keywords: fairy tale, Gothic, masculinity, race, disability, queerness.

Disney's selection of Guillermo del Toro for a darker, live-action adaptation of Pinocchio (2021) confirms an essential element distinctive of his films. As Michael Atkinson notes, all Del Toro's films "are fairy tales, even when they're science fiction, horror, straight fantasy or some coyote admixture therein. His sensibility is Grimmian, born of urban-Mexican culture steeped in native-arts crafts, poverty, simmering civil discontent and American pop" (50). While critical attention has largely focused on Del Toro's overt fairy tale Pan's Labyrinth (2006), Atkinson is accurate in highlighting that Del Toro's Hollywood films all incorporate the mythic, moral, and gothic qualities found in the Brothers Grimm, as the filmmaker crafts new tales that draw on the ancient. His fantastical tales are not for children yet still present vital lessons embedded in these archetypal journeys - and their audience's memories. His free borrowings from fairy 
tales and popular culture deliberately connect the familiar to his uncanny worlds, adding weight to any moral within.

While these folklore tales predate gothic novels, they contain many of the same qualities. Lisa Hopkins notes the Gothic's "aesthetic of violent contrasts" (xii), with the polarities of youth and age, beautiful and ugly, kindness and evil, innocence and knowledge. Also, as it happens in Gothic fiction, the sins of the parents may be visited on their children, with key action taking place in dark, removed spaces: dungeons, attics, towers, forests, huts. While the uncanny and supernatural in the Gothic is often a threatening force, in fairy tales the supernatural has the potential for good or bad-sometimes within the same source. Without the curses in "Beauty and the Beast" or "Sleeping Beauty," there would be no chance for redemption and love.

Del Toro has offered this explanation for the fairy tale elements in his work: "they tell the truth, not organized politics, religion or economics. Those things destroy the soul" (qtd. in Canfield, italics mine). Jennifer Orme notes that some critics were uncomfortable with how Pan's Labyrinth fable was entwined with the politics of the Spanish Civil War, wishing that Del Toro's film had either focused on the War or a fairy tale. However, she argues that this confluence was central to the theme of Pan's Labyrinth, as the "hybrid nature itself constitutes a form of disobedience to audience expectations of each of these genres by combining genres that are normally distinct" (220). Del Toro's Hollywood fairy tales may likewise promote this disobedience through hybridity - yet they are subtler, with political concerns relegated to subtexts that gives weight to his fantastical characters' journeys.

While fairy tales are at least a subtext in his Hollywood films, they are foundational to two of his films: Hellboy II: The Golden Army (2008) and The Shape of Water (2017). The prologues of both films include a fairy-tale narrative structure/device. Likewise, these films contain allegorical elements that critique social inequities through their fantastical characters. The contemporary politics of race, sexuality, gender, and environmentalism are embedded within these original Hollywood fairy tales. These two films are further linked in complicated ways. Though Hellboy II is technically a comic book adaptation and a sequel to his film Hellboy (2004), its story was largely original, allowing Del Toro creative latitude. While The Shape of Water may appear to be Del Toro's Hollywood film the least constrained by genre, it shares enough similarities with Hellboy II that some viewers have asked if The Shape of Water is an unofficial sequel. However, I suggest that Hellboy II was more of a rehearsal for Del Toro's the structure of The Shape of Water, using hypertextual construction to carry his political objectives.

Guillermo del Toro's films are not only expressions of his gothic sensibility and his immersion in literature and popular culture-he crafts moral tales that challenge as much as they delight his audiences. This essay will focus on the intersecting political messages woven into Hellboy II: The Golden Army and The Shape of Water, messages amplified not obscured by their fairy tale delivery. Through rich textual references, intersections, and hidden subtexts, Del Toro creates new Gothic fairy tales, with original protagonists emerging from the margins. By 
resisting previous patriarchal and racial boundaries, these films challenge their audiences to embrace new paradigms.

\section{A DeVishly RoMANTic SUPERHERo}

Before discussing Hellboy II: The Golden Army, it is important to note how Del Toro shaped a superhero protagonist whose gothic and liminal position allowed him to bridge the fantastical and political tensions fully explored in the sequel. Del Toro traces his gothic sensibility to watching Wuthering Heights (1939) when he was a child: falling asleep and waking up, the gothic atmosphere seeped into his consciousness more than narrative (Calia). As a drowsy toddler, he absorbed the powerful force of love, without its pathology or tragedy.

Though others may also use the term horror to describe Del Toro's films, it is a label that the director resists - even when his protagonist is the spawn of Satan or an Amazonian creature. In his Hellboy films, Del Toro evokes the nightmare of his characters' exclusion as well as the humanity and beauty within his characters, no matter how frightening-exploiting the tension between awful and awesome. Cristina Bacchilega and John Rieder describe Del Toro's process of preserving the beauty within horror, strengthening the moral imperative within both: "The strategy of merging fairy tale and horror, and then making them the emotional and thematic partners of historical realism, insists upon the intellectual seriousness of these forms of popular culture that have been trivialized in the past" (35). Del Toro's fairy tales resonate because of their historical grounding and connections to social issues.

In the first film, Del Toro addresses the opening question posed by Hellboy's adoptive father Professor Broom: "What is it that makes a man a man? Is it his origins, the way things start? Or is it something else harder to describe?" This question establishes the character of Hellboy at the start as a and not a monster, defined by his choices and not his unfortunate birth or name. Del Toro's Hellboy is more interested in cats, candy bars, and television than the underworld. Though creator Mike Mignola collaborated on both of del Toro's Hellboy films, the protagonist of these films differs significantly from his other appearances. For example, in the 2019 Hellboy reboot, Hellboy takes great pride in being the "World's Greatest Paranormal Investigator" and operates alone. Del Toro's Red (as his friends call him) only wants love and acceptance, with his service to the Bureau for Paranormal Research and Defense merely a diversion from his broken heart. Red represented a new screen superhero, predating Tony Stark's wise-cracking persona in Iron Man (2008), choosing love over duty long before Captain America gave up his shield.

Even if Red resists being a figure of horror fiction, he remains firmly a gothic characterlike Quasimodo or the Phantom, he is hidden from the eyes of the world, relegated to observing. It remains ambiguous whether Red lives in his underground chamber as a son, guest, or prisoner. Elizabeth Parker and Michelle Poland explain the subtle construction of the Gothic as "with an understanding of fear that is more nuanced than what we see in typical or traditional horror films - those that rely on tropes and stereotypes-leading us beyond cheap 
scares and into a more profound feeling of 'insidious unease'" (8). The supporting characters of fire-starter Liz Sherman and the fish-man Abe Sapien contribute to this unease, as their powers express the untapped potential of nature. Despite their good intentions, they are figures of dread for exceeding what can be contained or understood by humans. In addition to being marked physically as otherworldly, they also possess mental powers that add a psychological aspect to the gothic dread they produce.

Having crafted this genre-bending superhero, Hellboy II: The Golden Army used the opportunity of the sequel to add both a fairy tale subplot and incorporate sociopolitical themes. The prologue presents Red as a young boy, watching Howdy Doody and awaiting Santa Claus-both of whom Red assumes are real. For his bedtime story, his father Professor Broom reads the tale of the Golden Army, an indestructible force commissioned by the elven King Balor. Though originally, "men, forests and magical beings" dwelled in harmony, the destructive nature of Man led King Balor to allow the goblin-blacksmith to forge the Golden Army. However, King Balor could not stomach bloodshed of this unstoppable force. Ignoring the advice of his son Prince Nuada, he offered Man a truce-de-activating the Army and dividing the Crown that controls them. Prince Nuada exiled himself, pledging to return when his people needed him the most. This fairy-tale prologue establishes the environmental concern of the film - with the forests and magical beings aligned-while echoing the United States' breaking of treaties with indigenous people, who likewise valued the preservation of forests and wildlife.

As an indication of the consequence of this original fairy tale, Del Toro commissioned Neil Gaiman, an acclaimed author known for his rich fantastical worlds, to create it. Father's reading from an old book to Red was then brought to life with puppet animation. Kristine Kotecki notes the authority of "print fairy tales being associated with an idealized and ageold folk knowledge" (238), an authority that this scene claims. This prologue's blend of fairytale motifs and popular culture set the style of this film, displaying "a 'hypertextual' aesthetic, engaging the film's audience with a network of links to follow and metatextual commentaries to process" (Kotecki 243). The omnipresent television and popular music are appropriate for Red as his only link to the outside world - which may explain why it may be challenging for Red to know what is real and what is make-believe. As an adult, Red's bunker has a dozen TV screens, all presenting a different mediated image of the outside world. Like other gothic figures, he is doomed to watch the world go by.

In fairy-tale fashion, Prince Nuada reemergence in present-day Manhattan is due to Mankind's breaking of their treaty. Humanity's greed and disrespect has destroyed the ancient forests, relegating magical beings to abandoned railway yards and hidden tunnels. It is not coincidental that the Prince first strikes at an art auction, where ancient relics are being sold to privileged people with no respect for their spiritual value: the first item on the block is an ancient fertility goddess. Prince Nuada enters as the auctioneer places the segment of the Royal Crown of Bethmoora on the block, labelling it part of a "lost culture." If Prince Nuada's 
only intention was to retrieve the Crown segment, he could have done so with minimal violence. Instead, as punishment, he slaughters everyone present, proclaiming, "Proud, empty, hollow things: let me remind you why you used to fear the dark." Nuada releases "tooth fairies," winged Black Forest beings who voraciously consume living calcium, leaving nothing of their victims but goo. Through the geographic origin of these tiny yet terrifying fairies, Del Toro deliberately evokes the ambivalent qualities of Grimmian tales, with violence the consequence for the auction's objectifying of ancient cultures.

Complicating the battle at the heart of this film is that Prince Nuada's return-and his goal to awaken the Golden Army-is tied to ecological conservation. Keith McDonald and Roger Clark compare the strong presence of ecological issues in Del Toro's films to the work of his friend director James Cameron (8). Similar to the character of Thanos in Avengers: Infinity Wars (2018), Prince Nuada justifies his ambition by citing Mankind's disrespect for planet resources, natural as well as super. As established in the prologue, Mankind pledged the forests to King Balor in exchange for deactivating his indestructible Army. With magical beings exiled from the forests, Prince Nuada's people do need him, almost absolving his patricide to seize the throne. Del Toro's fairy tale construction allows sentient magical beings to stand in for forests, rivers, and animals that cannot speak, representing a formidable threat, evoking the ecoGothic. As Addie C. Booth defines, "the ecoGothic indicates a method of inquiry for understanding the darker, more disturbing aspects of human relationships with nonhuman nature," highlighting the fear, anxiety, and dread that defines those interactions (755). Like the tooth fairies, the magical beings in The Golden Army are dark, complicated, and beautiful, demonstrating the perils of disrespecting the nonhuman natural world.

Prince Nuada cleverly links his battle against Mankind to Red's own position, as he is likewise marginalized and unappreciated. Red is confined to the subterranean Bureau headquarters, transported to missions in a garbage truck. Instead of recognizing his work, his Bureau handler actively denies his existence, denouncing any sightings as "ridiculous" on television. When Liz's blaze exterminating the tooth fairies expels him to the sidewalk, Red shouts "we are out," reveling in being freed from his closeted existence. Red yearns for a relationship with people beyond the television images in his bunker, yet the public responds by calling him names and pelting him with beer cans.

When his relationship with Liz is also revealed, he is accused of promoting interspecies relationships, challenging traditional marriage. In addition to the film's link to ecological concerns, Red is simultaneously a queer and racialized figure, as he strives to be less threatening and assure people that he just wants to be "normal-like you, you, everyone." Prince Nuada's taunt that humanity hates him, that Red has more in common with Nuada and his magical people, is continually confirmed, both by Red's interactions with people and as reported on his televisions. He does not realize that he and his companions exhibit humanity that exceeds those with only human DNA. These transhuman or posthuman figures present a "rejection 
and a reconfiguration of the values of the traditional humanist subject" (Bolter 2), with Mankind as the ultimate villains whose greed is responsible for this conflict and destruction.

The action of Hellboy II: The Golden Army places the supernatural agents of the Bureau for Paranormal Research and Defense at odds with the humanity that they have worked to protect. Like the kingdom of King Balor, Red and his colleagues have been used and unappreciated. The ecoGothic asserts its power throughout this film, moving from "unease" to threat as it fights for its survival.

\section{THE PRINCESS BREAKS THE SPELL}

The Golden Army also introduces a second love plot that connects the fairy-tale narrative to the franchise's main characters, as well as crafting a unique Princess. Complementing the next stage in Red and Liz's relationship, Abe Sapien-discovered beneath a foundling hospital in 1865 and labelled Icthyo Sapien -falls in love with Princess Nuala, Nuada's twin sister. Princess Nuala opposes her brother's ambition to awaken the Golden Army, hiding her piece of the controlling Crown from him. Abe and Nuala share the challenge of being exiled from their natural element (respectively water and the forest), as well as having the ability to probe peo-

ple's minds with their touch-probes that are not always invited. Though unsettling ecoGothic figures that resist containment or definition, they maintain a benevolent attitude toward humanity - as well as the "human" desire to love and be loved.

Significantly, Abe and Nuala first meet in the Troll Market, surrounded by marginalized yet diverse and awesome figures. This hidden space emerges as a place of acceptance-Red describes it to Liz as a place that he will bring her to, where no one will stare. The bodies in the Market are not idealized figures, representing instead a range of physical configurations, demonstrating a lack of speciesism. Hidden from the eyes above, they can circulate freely. In the Troll Market, "normal" is not limited to human.

With Abe and Nuala's voiceless communication, as well as their non-binary presentation, this couple anticipates David T. Mitchell and Sharon L. Snyder's reading of The Shape of Water, with its "complex crip and queer embodiments over metaphors of voicelessness" (153) - with speech often an inadequate prosthesis for expression. Adding to the queerness of this couple is that it is technically a triangle: the royal twins Nuala and Nuada are psychically linked, to the extent that they experience each other's thoughts and physical sensations. Nuala can only partially cloak her link with her brother-both implicating him in her relationship with Abe, as well as preventing her from shielding Abe from her brother. Nuala and Nuada exist simultaneously as two individuals, and as one person with two genders and naturesfurther complicating gender in this franchise. McDonald and Clark connect Del Toro to other transnational directors whose work all "provide counter-discourse perspectives to heteronormative, straight narratives" (6), bringing a "queer appeal" to these romances. 


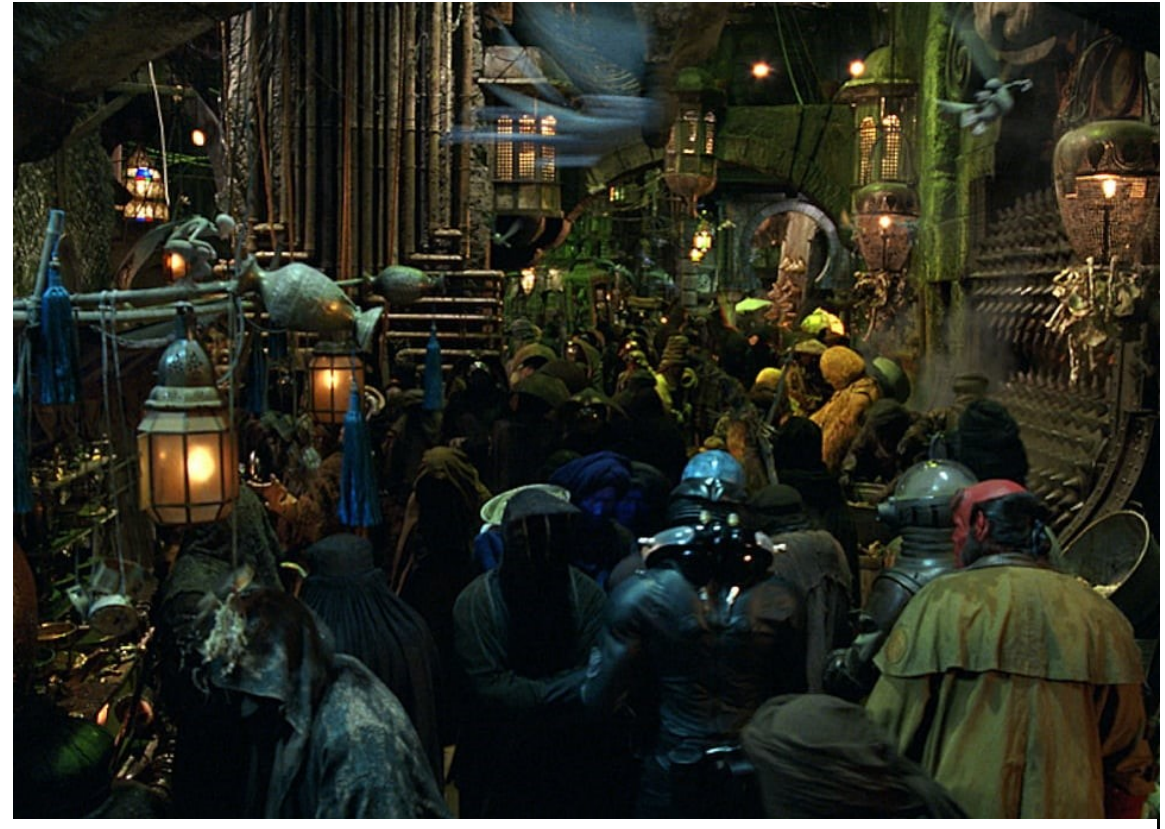

Figure 1 Red (lower right corner) strolls unnoticed in the diversity of the Troll Market.
Like Red, Abe must question where his loyalties belong, as he is torn between his love for Prince Nuala and his duty to the Bureau. Yet Abe consistently chooses love, with a woman who is most like him. However, by sheltering Princess Nuala, he puts Red's life in the balance. And when Abe pays Prince Nuada's ransom with the Crown piece, he allows the Golden Army to come to life. Abe declines to consider Mankind (that has never considered him). While Abe has previously played the celibate third wheel, watch-

ing Red breaking rules for Liz, he now asserts himself as a romantic (and potentially sexual) being. When Red formally challenges Prince Nuada for the Crown that controls the Golden Army, Abe impedes him: Abe explains that if Red kills Nuada, Nuala will die as well. Red acquiesces, leaving himself and Mankind vulnerable - for the sake of Abe's love for Nuala.

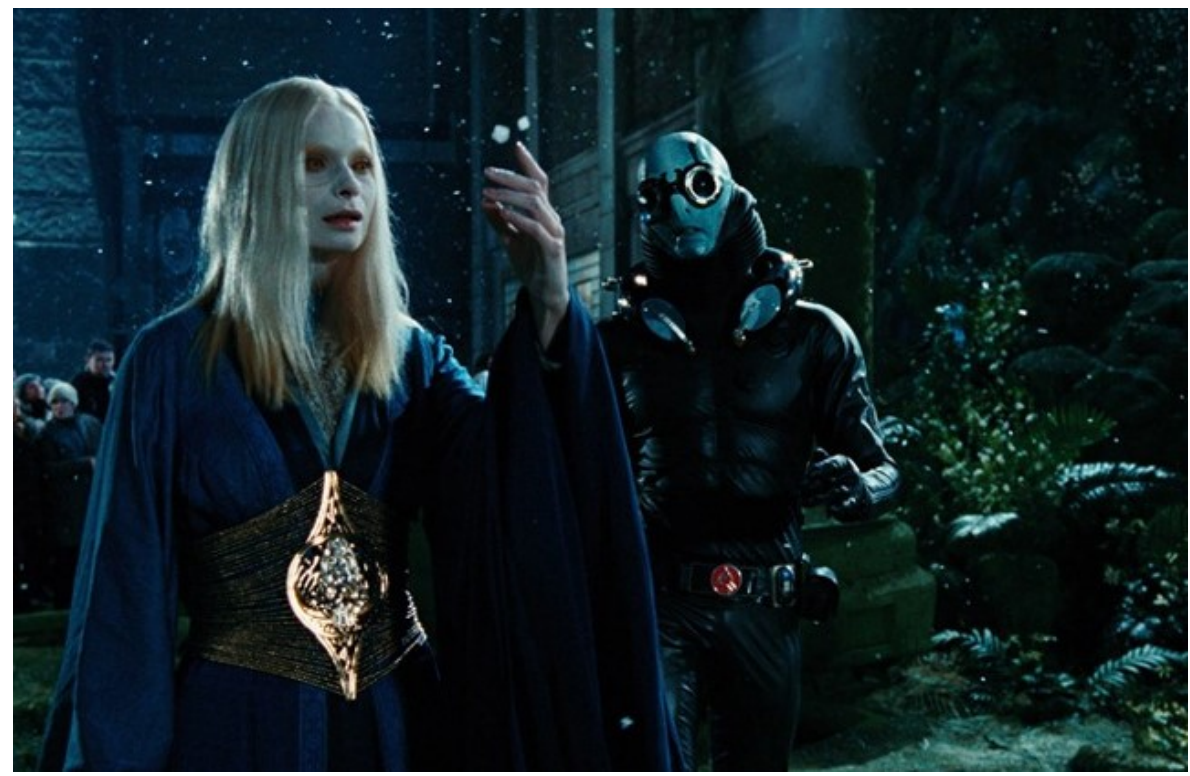

Figure 2 Nuala and Abe share their grief over the death of the awesome Elemental, the last of his kind.

However, Princess Nuala instead asserts her role as the hero, declining to be anyone's hostage or prize. As the Princess, only she can truly challenge her brother's right to the Crown. By 
committing suicide, she removes herself from the equation, as well as killing her brother. However, as noble as her action might be, she has left the natural and magical world without a champion-as well as robbing Abe of his chance at love. Princess Nuala chooses her father's pledge to humanity and fratricide, over love with her fish-man. Yet though she died to preserve humanity, the final choices of the supernatural agents of the Bureau for Paranormal Research and Defense make Mankind's victory more ambivalent: following Prince Nuada's example, Agent Krauss, Abe Sapien, Red and Liz (carrying unborn twins) choose exile together, no longer willing to serve Man from the margins.

In these characters' search for a new home, away from the eyes of Man, they reject social death and fear-based labels-choosing to live the life in the wilderness that Frankenstein's Creature had imagined with his bride. The sacrifice of Princess Nuala made these choices possible, reminding the viewer that loss is often essential for a happy ending, as they build their new community.

\section{Del TORO's SAVIOR PRINCESS}

When Guillermo del Toro saw The Creature from the Black Lagoon (1954) as a child, he thought it was a romance, expecting the two would end up together. With The Shape of Water (2017), he corrected the ending: "The ideas I wanted to put in the movie, the reversal...to make the image of the creature carrying the girl a beautiful one, as opposed to a horror image" (qtd. in Erbland). Not only does Del Toro's amphibious creature resemble Abe Sapien, both characters are interpreted by actor Doug Jones. The Shape of Water is steeped in Del Toro's gothic vision, revealing the marginalized and the past that infect the visible present. With The Shape of Water, he presents a fable of crossing racial, national, gender and species boundaries-embracing instead courage, love, and acceptance.

Reviewing the timeline of 1960s Baltimore, it is clear that Del Toro strategically placed his fairy-tale romance at the intersection of the Civil Rights Movement, an emerging gay-lesbian community, the Space Race (Russia is ahead) and the Cold War, in a city adjacent to the Pentagon. In 1962, Baltimore's Civic Interest Group was actively organizing protests on Maryland's Eastern Shore (Baltimore), which was still largely segregated. Concurrently, though the city had several established gay bars, they were subject to raids and the aftershocks of Joe McCarthy's Lavender Scare ("LGBT"). Del Toro deliberately evokes these various tensions. Yet like much of 1960s culture, the characters prefer the distractions of an optimistic popular culture. This historical context of civil rights protests and the Cold War, deliberately repressed by the film's main action, adds Gothic undertones to the forbidden love story at the center.

Like his hero, Del Toro's "princess" defies expectations: Elisa is a foundling and mute, bearing the scars of her early abuse. Yet she finds joy in her life -- with her two friends, her shoes, and her daily orgasm. Being abandoned has taught her to be self-sufficient for her joy. Her friendships cross 1960s boundaries: Zelda is Black and Giles is gay, yet both accept her, ably reading her sign language. Working as a night cleaner in a government lab, Eliza is the 
first to recognize the man within the Amphibian, that government workers call the Asset. She actively courts the Amphibian-before organizing his escape to her apartment, with the help of her friends and the Soviet agent. Del Toro's construction falls within Stephen Shapiro's definition of speculative nostalgia, which "mixes the past with an idea about an alternative lifeworld...to build a new social formation" (121). Drawing on gothic tropes, with much of the action in hidden spaces, Del Toro presents invisible figures that defy restrictions of Maryland 1960s to celebrate an unimaginable love. 1950s monster movies such as The Creature of the Black Lagoon, drew their horror from the repressed fears of the Cold War, sexuality, and race. In his reversal from a horror film to a romance, del Toro deliberately chose to set his film at the intersections of these fears, making both the subtext and the repressions more visible.

The Shape of Water opens with a lush dream sequence of Eliza's flooded apartment and this voiceover (by Giles) that sets up both its fairy tale and historical context:

If I spoke about it - if I did - what would I tell you? I wonder. Would I tell you about the time? It happened a long time ago, it seems. In the last days of a fair prince's reign. Or would I tell you about the place? A small city near the coast, but far from everything else. Or, I don't know... Would I tell you about her? The princess without voice. Or perhaps I would just warn you, about the truth of these facts. And the tale of love and loss. And the monster, who tried to destroy it all.

Del Toro says he chose to set the film in the year 1962 to show the hidden horrors of the period he sees referenced with "Make America Great Again": "Everything was super-great if you were white, Anglo-Saxon, and Protestant, but if you were anything else, you were fucked" (qtd. in Erbland). In line with Del Toro's explanation, the "monster" Strickland is a White suburban father and husband. And despite the "reign of the fair prince" Kennedy, racial protests in Baltimore and elsewhere were more likely to be met with violence than with progress. Though Baltimore is described as "small city near the coast, but far from everything else," it is not far from the Pentagon and the industrial military complex. The action of the film begins September 17, 1962, ending October 10, 1962-days before the Cuban Missile Crisis.

This social and political context is part of the fabric of this fairy tale, as actively represented by the supporting characters. Eliza's neighbor Giles is an isolated, gay man in his 60s, whose alcoholism made him lose his advertising job. Her best friend and co-worker Zelda is a married Black woman, who works with Eliza in the underground government laboratory. The lead scientist Dr. Robert Hoffstettler, dedicated to the care and understanding of the Amphibian, is actually the Soviet double agent Dmitri. Their nemesis Stickland is the government agent who brought the Amphibian from the Amazon, yet he is also an over-compensating family man. This Baltimore laboratory presents the intersection of the Soviet and U.S. militaryindustrial complex - who believe their captive Asset may provide an advantage in the Space Race-with harassment of gay men, Blacks, and women an accepted part of the workplace. However, the characters of this film live in active denial of their political reality. 
Del Toro often balances his borrowing from classic fairy tales with popular culture references, but none so much as The Shape of Water. Kotecki explains that "hypertextuality creates resistance to the constructs assumed of 'canonical' literary fairy tales" (236). Eliza and Giles share the upstairs space of a failing, third-run movie theatre. Giles exclusively watches 1930s40s musicals, escaping the social tensions that could be found in 1950s horror, spy, or social problem films - while Red watches television as a window to the "real" world, Giles uses TV to escape what is outside his apartment.

The first clip viewed is from The Little Colonel (1935), featuring Bill Robinson's stair dance with Shirley Temple. Though Giles notes how hard that was to dance, he glides over how Robinson's innovations were stolen by James Cagney and Hollywood. Like Red, Giles finds it challenging to be accepted by real people, as he also finds comfort in television and cats. These escapist texts that Del Toro places on television or the movie theatre below contain images of resistance and integration-even while Giles ignores those messages, preferring the comforting narratives.

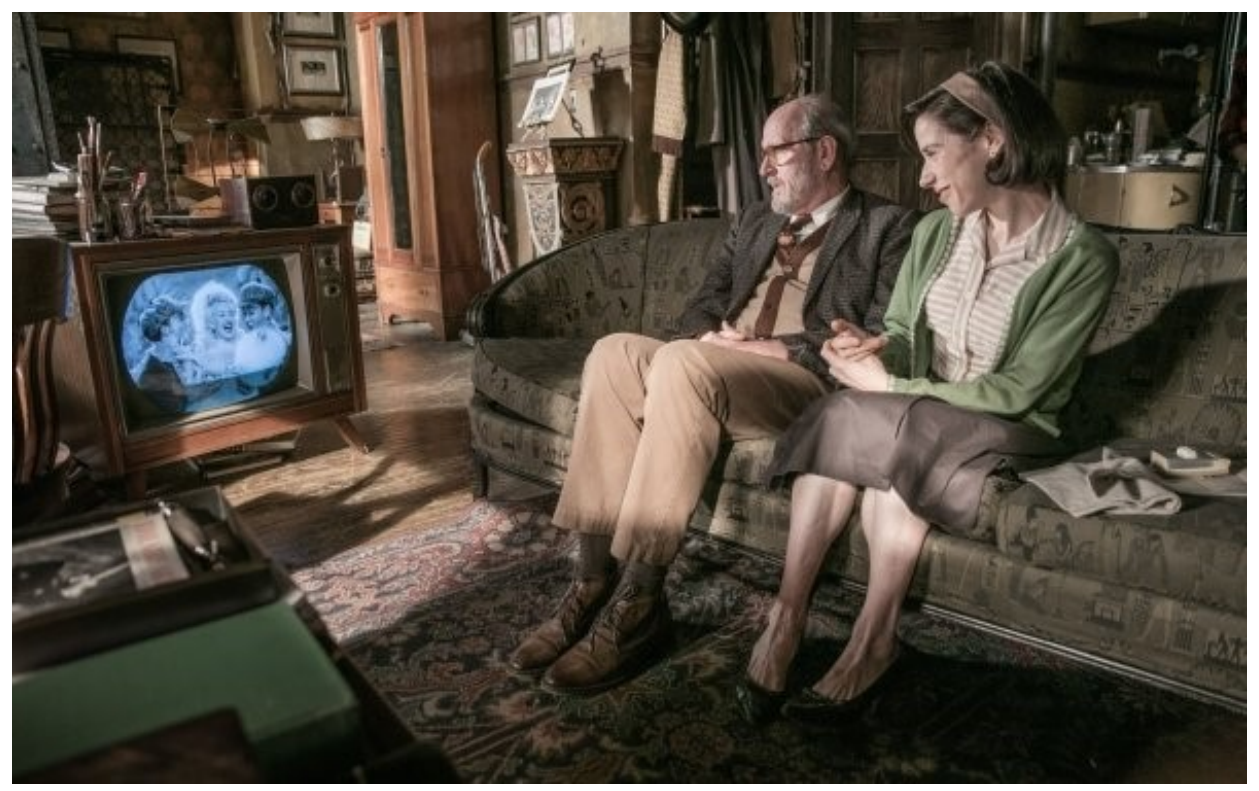

Figure 3 Giles takes refuge in televised musicals and Eliza's friendship.

An example of how Del Toro weaves these elements together is evident in a scene that follows Eliza's first meeting the Amphibian. She and her neighbor Giles are sharing a "sordid" pie from a new franchise ("the latest thing!"). As he clears the plates, Eliza turns the TV to the news, reporting police violently breaking up a civil rights protest; from the next room, Giles shouts: "Oh, God, change that awfulness. I don't want to see that; I don't want to see it." Instead, she switches to Betty Grable dancing with a costumed horse to "Pretty Baby of Mine." Though as a closeted gay man, Giles might be expected to have sympathy for others' rights, he prefers to escape to 1940s musicals, oblivious to the coded miscegenation that dances across his living room. On the other hand, Eliza embraces the joy within these musical interludes, 
tap dancing on her way to work. It is this joy and curiosity that has prepared Eliza to meet her prince, while her awareness of the darker side of life allows her to disregard others' judgments.

Significantly as the narrator of the story, Giles is the figure most trapped in his selfloathing and denial of the tensions around him. Unemployed, Giles is carrying on a desperate flirtation with a younger counterman (despite how unappetizing the pie he serves is). On a later visit to the counter, his crush harshly turns away a Black couple from sitting at the empty counter, followed by Giles meek, "You didn't have to be so mean." But just, a few minutes later, Giles is likewise banned from the restaurant when the Pie Guy realizes Giles' intentions: "This is a family restaurant." Giles may quietly applaud resistant figures like Alice Faye-but he still supports the status quo, as he draws advertisements of happy families, despite his marginalized and quietly desperate life.

Yet while Giles may be in denial of his social marginalization, Eliza denies society's ability to limit or define her-instead she finds freedom in the margins. Del Toro strategically places his lovers at a point in U.S. history that was socially and politically volatile-while many others were actively in denial of lives who existed outside of television's America.

\section{THE Love THAT CANNOT SPEAK}

Though his couple may have come from a monster image, Del Toro's love story draws on classic fairy tale figures, most strikingly the Little Mermaid and the Frog Prince. In her discussion of Pan's Labyrinth, Kotecki notes how "an older form approximating a newer one can produce an innovative effect" (236). While Del Toro's canonical models were about hybrid beings striving to become human, this tale celebrates their differences and the sea.

Eliza subverts her fairy tale roots by actively resisting social expectations and constraints. Rather than being a sweet and innocent girl, she is a complicated woman. After the opening sequence, Eliza begins the ritual for her "day" (waking at 9:00pm), boiling eggs for her lunch and then using the egg-timer to masturbate in her bath. She also has an appetite for nice footwear and prefers to wear jewel tones over pastels. While the Mermaid traded her voice to the Sea Witch for legs, Eliza's voice was stolen by her unknown abusers. Like the Mermaid, she was found by the river yet raised in a Catholic orphanage (her origins echo Abe Sapien's). But again, Eliza does not fit the mold of the sweet orphan-she has no qualms about being late to work and breaking in line to clock in. Despite his swagger, she is not intimidated by Strickland. Eliza most subverts expectations, canonical and sociopolitical, in her recognition and pursuit of her Prince.

Instead of being the object of her Prince's gaze, Eliza is immediately curious about the Amphibian. Despite the dangerous potential of the Amphibian (she and Zelda are called in after his attack on Strickland), she is not deterred. As they mop the blood-smeared lab, Eliza retrieves Strickland's fingers, calmly putting them in her lunch bag. While Zelda is rattled by the blood, Eliza approaches the Amphibian's tank, placing her hand against the glass - he is 
the one who retreats. Throughout the film, Eliza pursues the Amphibian. She first seduces him with hard-boiled eggs, showing little fear when he rises fully from his pool and shrieks. On her next visit, she adds music to her pursuit. Rather than the beast reassuring the beauty or carrying her off, Eliza is the one who proves herself to the Amphibian, readying herself to rescue him.

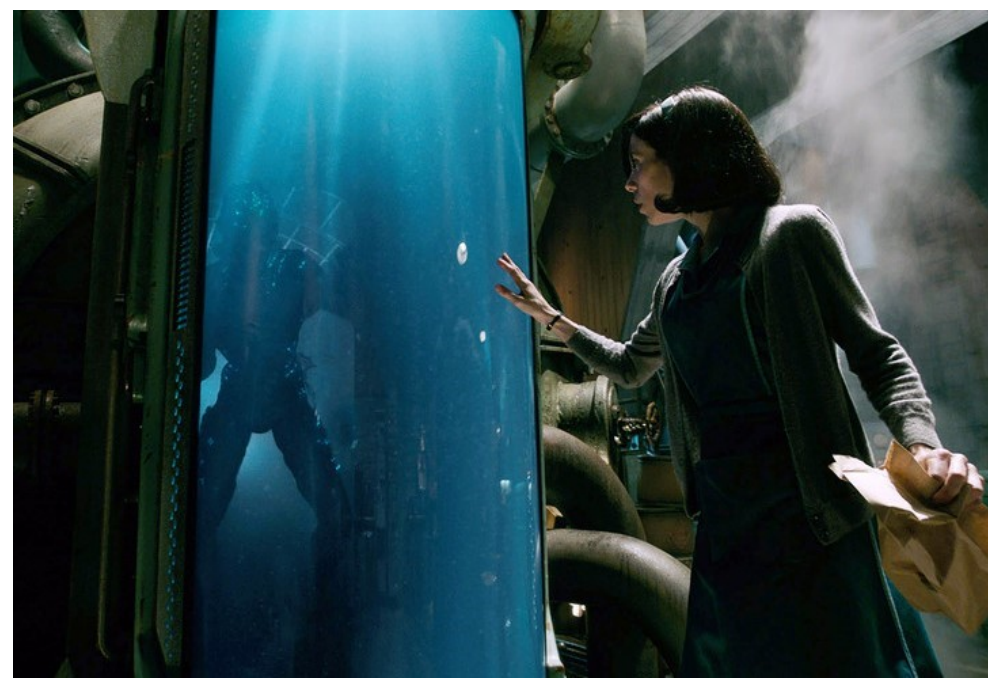

Figure 4 Eliza gazes at the Amphibian, beginning her courtship of him

One quality that united Eliza and the Amphibian across species is their apparent voicelessness. But their lack of traditional speech is ironic - as they may be the most comfortable in expressing their needs and who they are. Mitchell and Snyder describe the film's integration of voicelessness with political and queer coding: "Elisa's surgical neck stars, the Amphibian figure's gills, and their parallel communication disabilities connect them as objects of fascination for an intrusive normative medico-militarized gaze" (153). On the other hand, Eliza teaches the Amphibian to "speak" through sign language. Her signing in several instances gives her "a voice" not available to others. And unlike Abe and Nuala, their love is consummated, with the film acknowledging their desire and sexuality.

Notably, voicelessness is not unique to Eliza and the Amphibian. As Mitchell and Snyder note, "voicelessness is often regarded as a metaphor for political powerlessness" (151). This powerlessness obviously silences Zelda and Giles, but White men Strickland and Hoffstetler are likewise silenced by their precarious position within patriarchal order. Not only do Strickland and the General ignore Dr. Hostetler's pleas on behalf of the scientific and individual value of the Asset, but Dmitri's Soviet handlers also ignore him.

Most ironic is the ultimate voicelessness of Strickland - despite being someone who uses speech to intimidate others. He makes frequent comments against the humanity of nonWhites and non-Americans (comments strangely echoed by Giles early in the film). Yet the Amphibian and his loss reveal Strickland's tenuous position. Despite his brutal nature, Strickland takes pride in his service to society and his family, humbly asking General Hoyt: "When is a man done proving himself, a good man, a decent man?" Hoyt makes it clear that one failure is enough to exile Strickland to an "alternate universe of shit." Strickland experiences metaphoric castration throughout the film (losing his fingers first to the Amphibian then to rot, Giles' side-swiping his new Cadillac). Finally, the Amphibian takes Strickland's voice and his life, after his gunshot proves impotent. Evangelina Kindinger notes del Toro's evoking patriarchy's menace in Crimson Peak (2015): “The real horror, del Toro suggests, are not the 
ghost but patriarchy, because it traumatizes women and turns them into ghosts and monsters" (63). If Crimson Peak is about how patriarchy traumatizes women, Del Toro's Hellboy films and The Shape of Water ask how a man can survive patriarchy. While the male characters in The Golden Army turn their backs on patriarchal service, Strickland does not survive his blind loyalty.

As in The Golden Army, the Amphibian embodies the ecoGothic, with abilities and origins that create unease-an alternate masculinity with no connection to patriarchy, that evokes more questions than answers. In the Amazon, he protected natives who were resisting oil drilling. While Giles and Zelda see the Amphibian as Other, Eliza sees her union with the Amphibian fated by their shared difference (as with Abe and Nuala, or Liz and Red). When Giles calls the Amphibian "a thing" and therefore not worthy of rescue, Eliza challenges Giles' definition of human:

What am I? I move my mouth, like him, I make no sound, like him. What does that make me? All that I am... all that I've ever been... brought me here, to him. When he looks at me, the way he looks at me, he does not see what I lack or how I am incomplete. He sees me for what I am as I am. ...I can either save him or let him die.

Like Romeo and Juliet, The Shape of Water is a love story that serves to transform the community left behind by the persecuted lovers. Through Eliza and the Amphibian, Giles, Zelda, and Dmitri/ Hoffstetler found their voices-before Eliza's heroic example, it would not have occurred to any of them to "break the law," despite how poorly the law has treated them. Dmitri gave his life for his chance to speak, brutalized by agents of both the Soviet and U.S. governments. However, Giles and Zelda survive within their marginalized communities but now with a voice to speak against their oppression as well as the oppression of others. In Shapiro's terms, Eliza demonstrates how "an individual's suffering can function as more than merely an object of empathy, but can also stand as a scaffold for mutually enabling development through coalitional alliances" (132). Eliza has revealed herself to be their Princess; instead of the Authority, Strickland is the vanquished Monster.

In Del Toro's version, the landlocked Mermaid does not die and the Frog Prince does not become human - her love and sacrifice restore his strength, which he uses to save her life and make her amphibious. To get to the canal, Giles and Eliza must half-carry the Amphibian-where they are overtaken by Strickland, who shoots both the Amphibian and Eliza. However, the Amphibian heals himself, confronting Strickland and slashing him across the throat (mirroring Eliza's scars). It is at this point that he picks Eliza up in his arms-in the Black Lagoon pose-jumping into the canal. As he kisses her holding her neck, she revives and breathes through her new gills.

Some critics and viewers have noted this transformation as proof that Eliza was always more than human, making her even more the Mermaid, with the Amphibian the only one to recognize her true nature. In Donna Haraway's terms, The Shape of Water is an "argument for pleasure in the confusion of boundaries and for responsibility in their construction" (7). The 
Amphibian is the Prince who awakens Beauty-affirming her potential to be extrahuman. Neither the Frog Prince or the Little Mermaid in Del Toro's version aspire to be human - they embrace their differences and each other, finding a better place to live.

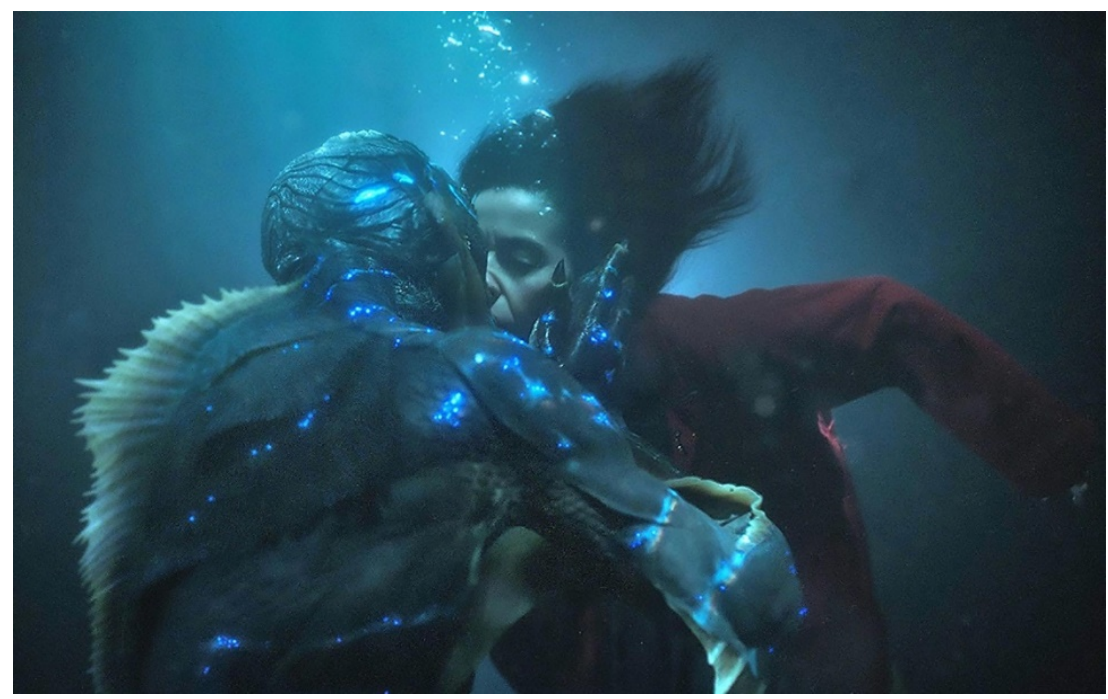

Figure 5 The Amphibian's kiss revives and transforms Eliza.

As a child, Del Toro instinctively saw the political power in the image of the hybrid man carrying the distressed woman. By choosing 1962, Del Toro not only places this final image as an argument for mixed marriages (Maryland only repealed its miscegenation law in 1967), but it argues for recognizing the humanity in all marginalized people, as well as the dangers of unchecked patriarchy. Eliza refuses to be marginalized by her past trauma or by men like Strickland, empowering everyone to resist "the monster, who tried to destroy it all."

\section{CONCLUSIONS}

Del Toro's has explained the message behind The Shape of Water's happy ending:

I think when we wake up in the morning, we can choose between fear and love. Every morning ...The way you end your story is important. It's important that we choose love over fear, because love is the answer. Silly as it may sound, it is the fucking answer to everything" (qtd. in Erbland).

As simplistic as this may sound, Bacchilega and Rieder see this as the strength that Del Toro draws from fairy tales, separating "the fairy tale's moral imperative from the condescension that so often attends the encryption of adult rules in fairy tale situations" (34). This kind of fairy-tale love is a political act at it defeats fear, scaling walls and ignoring difference.

Returning to Orme, Del Toro's hybridity is central to the defiance within his narratives, as he both engages and challenges his audience through his dizzying hypertextual combinations - mirroring the mosaic of the characters at the center of his films, who refuse "to submit to the narrative desires of others at their own expense" (219). His fairy tale structures pull his 
audience to root for endings that are not superficial - their love has been proven through their arduous journeys to lift the curse. As importantly, they are not stock princes/princesses, but characters that cross "natural" boundaries, finding the greatest humanity in the trans- or extrahuman. Del Toro's fairy tales are politically effective because their quests for true love are tied to being our best selves in a moral world-respective of definitions or boundaries.

\section{WORKS CITED}

Atkinson, Michael. “Moral Horrors in Guillermo del Toro's Pan's Labyrinth: The Supernatural Realm Mirrors Man's Inhumanity to Man." Film Comment vol. 43, no. 1, 2007, pp. 50-53. JSTOR www.jstor.org/stable/43754495. Accessed 8 April 2021.

Bacchilega, Cristina and John Rieder. "Mixing It Up: Generic Complexity and Gender Ideology in Early Twentyfirst Century Fairy Tale Films." Fairy Tale Films, edited by Pauline Greenhill and Sidney Eve Matrix. UP of Colorado, 2010, pp. 23-41.

Baltimore Civil Rights Heritage. baltimoreheritage.github.io/civil-rights-heritage/introduction/. Accessed 27 Aug. 2021.

Bolter, Jay David. "Posthumanism." The International Encyclopedia of Communication Theory and Philosophy. Wiley, 2016. DOI: 10.1002/9781118766804.wbiect220.

Booth, Addie C. "Hell [is] a pretty place, too": The Ecology of Horror in the Film Adaptation of Beloved. College Literature, vol. 47, no. 4, 2020, pp. 752-76. DOI:10.1353/ lit.2020.0038.

Calia, Michael. "Guillermo Del Toro on the True Gothic Romance of Crimson Peak." Wall Street Journal 12 Oct. 2015, www.wsj.com/articles/BL-SEB-91470. Accessed 15 July 2021.

Canfield, Jared. "Pan's Labyrinth Is Still Guillermo Del Toro's Best Movie." Screen Rant 2 Jan.2017. screenrant.com/pans-labyrinth-guillermo-del-toro-best-movie/ Accessed 1 May 2021.

Erbland, Kate. "The Shape of Water: Guillermo del Toro Explains Why His Fairy Tale is Really About a Different Sort of 'Disney F-ing Princess.'” IndieWire 12 Sept. 2017. www.indiewire.com/2017/09/the-shape-of-water-guillermo-del-toro-disney-princess-1201875416/. Accessed 7 May 2021.

Haraway, Donna. "A Cyborg Manifesto: Science, Technology, and Social-Feminism in the Late Twentieth Century." Manifestly Haraway. U of Minnesota P, 2016.

Hopkins, Lisa. Screening the Gothic. U of Texas P, 2005.

Kindinger, Evangelina. Crimson Peak, Nineteenth-Century Female Gothic, and the Slasher." NECSUS vol. 6, no. 2, 2017, pp. 55-71. necsus-ejms.org/the-ghost-is-just-a-metaphor-guillermo-del-toroscrimson-peak-nineteenth-century-female-Gothic-and-the-slasher/. Accessed 15 July 2021. 
Kotecki, Kristine. "Gothic Nature: An Introduction." Gothic Nature: New Directions in Ecohorror and the EcoGothic: Textual and Sociopolitical Authority in Guillermo del Toro's Pan's Labyrinth." Marvels \& Tales: Journal of Fairy-Tale Studies vol. 24, no. 2, 2010, pp. 235-54. EBSCOhost, search.ebscohost.com.ncc.idm.oclc.org/login.aspx?direct=true\&db=hus\&AN= $\quad$ 509973286\&site=ehost-live. Accessed 10 April 2021.

"LGBT History-Stonewall, Baltimore-style, 1955." Daily KOS 27 Oct. 2015," www.dailykos.com/stories/2015/10/27/1441385/-LGBT-History-Stonewall-Baltimore-style-1955. Accessed 25 Aug. 2021.

McDonald, Keith and Roger Clark. Guillermo del Toro: Film as Alchemic Art. Bloomsbury, 2014.

Mitchell, David T. and Sharon L. Snyder. “Room for (Materiality's) Maneuver: Reading the Oppositional in Guillermo del Toro's The Shape of Water. Journal of Cinema and Media Studies. vol. 58, no. 4., 2019, pp. 150-56. Project MUSE muse-jhu-edu.ncc.idm. oclc.org/article/730112. Accessed 20 April 2021.

Orme, Jennifer. "Narrative Desire and Disobedience in Pan's Labyrinth" Marvels \& Tales: Journal of FairyTales, vol. 24, no. 2 (2010), pp. 219-34. JSTOR www.jstor.org/ stable/41388953.

Parker, Elizabeth, and Michelle Poland. "Gothic Nature: An Introduction." Gothic Nature: New Directions in Ecohorror and the EcoGothic" no. 1, 2019, 1-20. Gothicnaturejournal.com/wp-content/uploads/2019/09/Parker-Poland_1-20_Gothic-Nature-1_2019.pdf. Accessed 1 July 2021.

Shapiro, Stephen. "Speculative Nostalgia and Media of the New Intersectional Left: My Favorite Thing is Monsters." The Novel as Network: Forms, Ideas, Commodities, edited by Tim Lanzendörfer and Corinna Norrick-Rühl, Palgrave, 2020, pp 119-36.

\section{FILMOGRAPHY}

The Creature from the Black Lagoon. Directed by Jack Arnold, Universal, 1954.

Crimson Peak, Directed and co-written by Guillermo del Toro, Universal, 2015.

Hellboy. Directed and written by Guillermo del Toro, performances by Ron Perlman, Selma Blair, Doug Jones, and Jeffrey Tambor, Sony, 2004.

Hellboy. Directed by Neil Marshall, Lionsgate, 2019.

Hellboy II: The Golden Army. Directed and written by Guillermo del Toro, performances by Ron Perlman, Selma Blair, Doug Jones, Anna Walton, Luke Goss, and Jeffrey Tambor, Sony, 2008.

The Little Colonel. Directed by David Robinson, performances by Shirley Temple and Bill Robinson, Fox, 1935.

The Shape of Water. Directed and co-written by Guillermo del Toro, performances by Sally Hawkins, Doug Jones, Richard Jenkins, Michael Shannon, Octavia Spencer, and Michael Stulhbarg, Fox Sea. 